\title{
Animal diet botanical composition compared with pasture species composition as indicators for pasture status in the semi-arid rangeland of Sudan (South Darfur State)
}

\author{
Awad O. Abusuwar ${ }^{1}$ and Elhadi O. Ahmed ${ }^{2}$ \\ ${ }^{1}$ Dept. of Arid land Agriculture, Faculty of Meteorology, Environment and Arid land Agric., \\ King A/Aziz University, Jeddah/Saudi Arabia \\ E-mail: abusuwar@yahoo.com \\ ${ }^{2}$ Ennhod Desert Sheep Research Station, North Kordofan State/Sudan
}

\begin{abstract}
A study was conducted during the period 2006/08 in the semi-arid rangeland of South Darfur State, Sudan at Eldien locality (latitudes $9^{\circ}-30^{\prime}$ and $11^{\circ}-45^{\prime}$ north and longitudes $25^{\circ}-30^{\prime}$ and $27^{\circ}$ east, ecologically in the low rainfall woodland savannah with an annual rainfall between 400-600 $\mathrm{mm}$ ).. The objective of the study was to evaluate animal diet botanical composition in comparison with pasture species composition as indicators for pasture status in the area. Data were collected for pasture species composition (Parker loop method, 1955) and animal diet botanical composition (Van Dyne Method,1968) over two years both in early wet and late dry summer seasons. Results showed that diet botanical composition was composed of pure herbaceous plant species during rainy and early dry summer seasons and a mixture of browse and herbaceous species in the late dry summer season. Calcium in animal diet was present in a suitable concentration, whereas phosphorous was present at low concentration. Although the percent species composition of the natural pasture provides an indicator of range composition, animal diet botanical composition could be used as an indicator of the pasture status. Both parameters could be very useful in designing range management practices, such as selecting species required for reseeding deteriorated range and in identifying key species that will form a base for range management.
\end{abstract}

Keywords: Pasture species composition, diet botanical composition, range condition, pasture status, $\mathrm{Ca}$ and $\mathrm{P}$ in animal diet

\section{INTRODUCTION}

Rangelands rank as a major land- type whether measured by size support for animal-based industries or as a source of stream flow and substantial portions of all major Continents are rangelands. Worldwide, 30 percent of the world land area is grassland (Stoddart, et. al (1975). A more useful measure of the importance of rangeland area is the contribution they make to animal production (Box 1971).

About $80 \%$ of the Sudanese population are in rural areas and are engaged in agriculture and highly mobile pastoral livestock production systems. In Sudan, $80-90 \%$ of the country livestock is possessed by nomadic tribes who depend on rangelands for livestock production. The livestock export contributes by almost $25-30 \%$ in the country national income (Darrag, 1990).

In arid zones, nomadic and transhumant (seminomadism) systems of livestock production prevail. In these systems high mobility for global grazing habit is the most efficient adaptation to the erratic rainfall .Movement from one area to another in search for good quality and quantity of feed and water is the rule. Transhumant or semi- nomadic systems have a home base, although they too are very mobile, with the majority of animals and the family away for several months and only 2-6 lactating cows are left at the base to provide milk for sale and for the utilization of the aged parents left behind. Feed from crop residues provide the main energy source during and shortly after the harvesting periods.

Open grazing is considered as a form of range utilization by nomads, which is the grazing of animals on a communal rangelands and communal resource base, under the concept that: range, water and lands are no ones property. Hans Rothenberg (1976) defined open grazing as the communal use of the grassland which allows every one to send any number of animals to the tribal or communal pastures. The pastures grazed by animals is freely 
available to all livestock of every tribe. Large number of animals using the free range resources at any time in any place, and the locations of these resources is determined by the herders.

Free grazing of rangelands is the most common feeding system for livestock production in Sudan. During the short wet season grasses grow and mature rapidly, producing abundant biomass, but with the onset of the dry season both quantity and quality of the pasture herbage decline and fail to meat the maintenance requirement of grazing animals.

Harrison (1955) defined and classified the vegetation zone of the low rainfall woodland savannah as part of open grazing land of the Baggara country in western Sudan and showed that this land is composed of grasses with bushes. Jackson and Harrison (1958) reported the effect of open grazing as overgrazing and trampling of pasture close to water yards and little use of pasture away from water yards. They also mentioned the factors that rationalized the continuation of open grazing system by the Baggara of western Sudan such as mud and irritating flies as push factors and good pasture and free water as attracting factors. Hans Ruthenberg (1976) indicated that the practice of unorganized communal grazing is the central problem of overgrazing, that is in the long run reducing the carrying capacity of the grazing area through overstocking.

The consequences of open grazing were tested by Heady (1975) who mentioned that too many poorlymanaged animals will cause overgrazing and vegetation deterioration through several commonly accepted stages. The most palatable species selected first and the continuous of the practice reduce the vigor of the plants. The space vacated by desirable species became the expanded home of less desirable species, and annual invaders. The drawback of open grazing in relation to time of use and damage was mentioned by Suleiman and Darrag (1982), that the nomads in the Sudan do not bother themselves with the proper time of grazing. In most cases they graze an area when the plants are not ready for grazing. Sometimes they graze when the soil is too wet, and this eventually cause damage to both plants and soils. Ibrahim (1962) mentioned the consequences and the degradation related to nomadism under open grazing system and stated that the major causes of ecological degradation in the Sudan is overstocking which led to overgrazing damages, subsequent depletion of palatable grasses and tree species and the destruction of soil- water balance and causing microclimate changes.
In the fragile environment of western Sudan there has been a controversy on whether sedentrization is better than nomadism, when it comes to practice and utilization of the limited resources of the area (Elham, 1988). The advocators of nomadism believe that the seasonal migrations involved in this mode of life allow more rational utilization of the resources. The opposers of nomadism, however, allege that the settlement of nomads brings about a better ecological balance, gives a better living conditions for the settlers through the provision of social and economic services. Pastoral cultures are associated with nomadism, with individual families or groups shifting from one place to another and with the season in response to the availability of forage and water or in some cases to avoid insects, (Lewis, 1961).

It is argued that grazing animals are powerful tool for a rangeland manager to use to either retain or alter species composition of grassland, (Whalley, 2000). Different grasses have different leaf stem ratio at least for some species. Those with lower ratios have slower growth rates than more valuable leafy species (Gardener, 1998).There is an increasing evidence, that grazing at high stocking densities for short periods of time followed by long periods of rest in appropriate seasons will swing the competitive balance in the direction of the leafier, faster-growing species and so produce a change in species composition (Whalley et al., 1999). Furthermore, determination of the ability of pasture to support livestock production in grazing land is important because the number of animals has an effect on the quantity of forage available to the grazing animals, thereby affecting intake and animal performance.

Attempts have been made in several African communities to encourage conservative land use, as was reported by Hunter (1990). The vegetation percent composition as a measure for determining the types and kinds of the natural pasture was of crucial importance. Humphrey, (1991) stated that the availability of pasture, the structure of the sward and nutritive values of its components reflects the characteristics of the species percentages and the environment which determines its senescence. Thus, the percent vegetation species composition is a measure and an indicator of range status in term of grasses, forbs and browse.

Under Sudan's savannah, the pasture is composed of annual grasses with some forbs species. Le Houerou,(1980) and Skerman (1965) showed that in the Baggara country of Kordofan and Darfur, where this study was conducted, grasses are high 
especially in the wooded grasslands of the poor savannah ecological zone. Forage from the natural rangelands in the Baggara communal land plays a vital role in providing feed to the livestock. The vegetation types and distribution, in the study area, are closely associated with rainfall, as the amount of rainfall increases from north to south, so do respective types, heights and diversity of the overstorey and under-storey vegetation, (El-Hag et al, 2003). The following shrubs and trees species are dominated on the sandy soils in the northern parts of the study area: Ziziphus spina Christi , Combretum cordofanum , Acacia senegal ,Gueira sensgalensis , Boscia senegalensis, and Calotropis procera .The herbaceous vegetation include : Cenchrus ,Zornia , Eragrostis , Aristida and Brachiaria species.

On the clay land in the south, over-storey vegetation is composed of Grewia tenax , Acacia mellifera , Anogeisus schimperi, Combretum spp. , Acacia seyal , Acacia gerrardii ,Acacia nilotica and Acacia seiberana. The herbaceous strata include Aristida funiculate , Dactyloctanium aegyptium ,Brachiaria spp. ,Hygrophylla spinosa ,Hyparhenia rufa , Setaria incrastata, Echinochloa stagnina and Tephrosia ,(Elzubier, 1984).

On native rangelands, a greater number of available plant species mean that cattle and sheep have more feeds to choose from. Thus, in large fields, cattle can adjust their diets and select plants that are more palatable and nutritious as the grazing season progressed. Holechek (1983) noted that in open park lands pastures, as dry season progresses, cattle diets contain greater proportions of forbs and shrubs. Forage stands are not diverse as seeded stands, but generally have a narrow season of palatability and this can create livestock nutritional problems. Moreover, the quantity and quality of the forage become more critical in the dry summer season and imposes more serious constraints to the development and productivity of these animals, (Darrag, 1995).

The type of soil may influence the composition of the pasture especially its mineral contents. Plants normally react according to the status composition in the soil. So, the quality of the forage is controlled by the mineral composition.(ARC,1980).

Plants often do not satisfy animal requirement of the grazing cattle, (McDowell, 1992).The same author stated that adequate intake by the grazing ruminants is essential to meet the minimum mineral requirement. In most tropical areas, mineral deficiency, imbalances and toxicities severely inhibit livestock production. The most important macro elements for livestock raised on natural semi-arid rangelands are calcium and phosphorous. Calcium is the most mineral element found in the animal body and is required in large quantities in addition to phosphorous. Many grasses contain adequate amounts of calcium, but legumes usually contain more calcium than other grasses and herbs. Dougall et al, (1964) found that average phosphorous concentration is less than that in legumes. Phosphorous deficiencies were reported by Fadellala, (1987) in the Baggara sheep studied in the low rainfall woodland Savannah of south Kordofan.

The objective of this study was to assess the quality of the pasture in terms of vegetation types by direct measurement of the pasture species composition and animal diets botanical composition to be used as indicators for pasture status in the semi-arid rangeland of the Sudan. Moreover, assessment of $\mathrm{Ca}$ and $\mathrm{P}$ in animal diet was another objective of the study

\section{MATERIALS AND METHODS}

Study area: The study was conducted in the Baggara belt of Dar Rezaigat communal land of South Darfur State. The area is located in the low rainfall woodland savannah between latitudes $9^{\circ}-30^{\prime}$ and $11^{\circ}-45$ north and longitudes $25^{\circ}-30^{\prime}$ and $27^{\circ}$ with an annual rainfall ranging between 400 and $600 \mathrm{~mm}$ (Fig. 1).

Open communal grazing of the livestock is a pattern of range use that prevails in this area. The nomads usually move with their livestock between the wet and dry season grazing locations in the north and south of the Baggara country.

Field study: Sampling of the vegetation during the period 2006-2008 was conducted in the wet and dry season grazing sites where nomads utilize the northern range pasture during and for a short period after the rainy season, then move to the south to spend the dry summer periods

\section{Methodology:}

\section{1- Vegetation botanical composition:}

This parameter was determined by the use of the Parker loop method (Parker,1951). Measurements were obtained as a percent hit of each plant species along the line transect or inside the $1 \mathrm{~m}^{2}$ quadrate. Percentages of plant species were finally classified as grasses, forbs and browse. 
Agric. Biol. J. N. Am., 2010, 1(5): 894-902

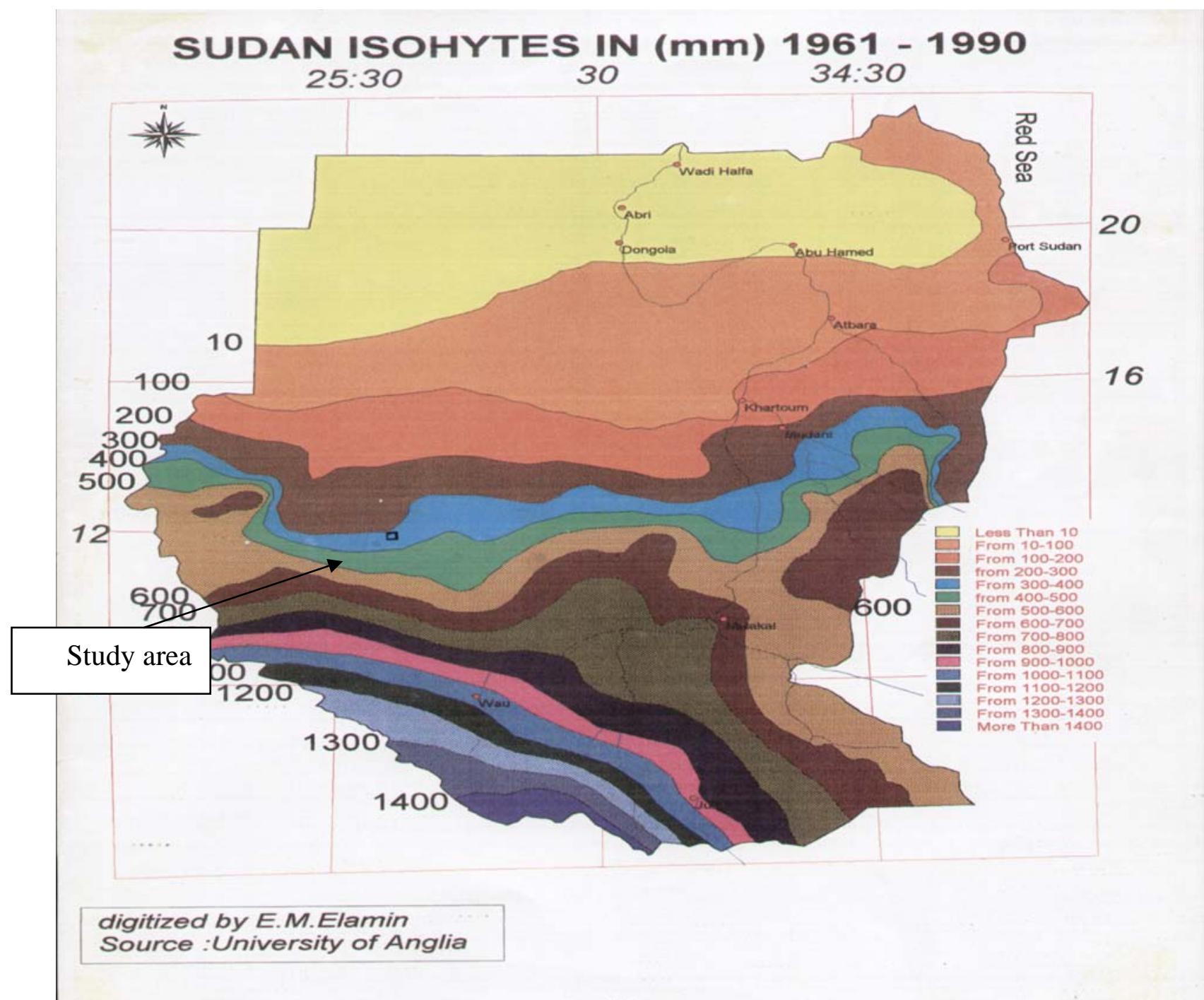

Fig.1. Sudan Isohyets in (mm) 1961-1990

2-Diets botanical composition: Diets selected by the free-grazing livestock (cattle, goats and sheep) in the wet and dry season grazing locations, were determined by the Bite-count Method (Van Dyne 1968). The method used to asses livestock diets botanical composition involved close observation of individual animal type selected from the herd. The animal was closely followed by an observer who identified and recorded the type and number of any plant chewed by the specific animal. Each animal was followed for two consecutive days in the morning and in the evening for 10 minutes each time and recorded in a sheet containing columns showing grasses, forbs and browse. Averaging the percentages of each plant species from the 100 readings of the animal bites will give the percentages of plant species selected by the different animal type as diets botanical composition.

Diet quality in terms of $\mathrm{Ca}$ and $\mathrm{P}$ : The plant species selected by each animal through the Bitecount Method were mixed together according their percentages included in each bite. Chemical analysis was performed on the samples for $\mathrm{Ca}$ and $\mathrm{P}$ determinations according to Chapman and Pratt (1961, 1968).

Data obtained from the field measurements (percent species composition and percent diet composition) were transformed using the Arc-Sin technique and statistically analyzed using the SPSS Multivariate Method and means were separated using the Duncan's Multiple - Range Test (Steel and Torre, 1980). 


\section{RESULTS AND DISCUSSION}

As indicated in table1, generally grasses dominated the range $(63-78 \%)$, followed by forbs $(10-18 \%)$ and browse $(9-19 \%)$. Percent composition of forbs and browse were almost similar. Grasses were significantly $(P<0.01)$ higher than forbs and browse both in early and late season grazing. Grasses and browse where higher in the second year regardless of the season. Forbs, however, were higher during the first year of the late season only.

Table 1. Percent vegetation composition as affected by year and season under natural rangelands

\begin{tabular}{|c|c|c|c|}
\hline Factors & Periods & \multicolumn{2}{|c|}{ Vegetation percentage composition } \\
\hline Vegetation composition & Years & early & late \\
\hline \multirow{2}{*}{ Grasses } & First year & 73.00 & 63.00 \\
\hline & Second year & 73.33 & 78.00 \\
\hline \multirow{2}{*}{ Forbs } & First year & 14.67 & 18.00 \\
\hline & Second year & 17.33 & 10.00 \\
\hline \multirow{2}{*}{ Browse } & First year & 12.33 & 19.33 \\
\hline & Second year & 9.33 & 11.67 \\
\hline \multirow{4}{*}{$\begin{array}{l}\text { Vegetation composition } \\
\text { effects: }\end{array}$} & Grasses \% & $73.17 \pm 10.80 a$ & $70.67 \pm 13.53 a$ \\
\hline & Forbs \% & $16.00 \pm 9.38 \mathrm{~b}$ & $15.00 \pm 7.44 \mathrm{~b}$ \\
\hline & Browse \% & $13.17 \pm 5.04 \mathrm{~b}$ & $13.17 \pm 5.04 \mathrm{~b}$ \\
\hline & Significance & $0.01^{* * *}$ & $0.01 * * *$ \\
\hline
\end{tabular}

*** highly significant at $(P<0.01)$

** significant at $(P<0.05)$

The availability of the pasture, the structure of the sward and nutritive values of its components reflect the characteristics of the species percentages and the environment which determine their growth and senescence (Humphrey, 1991).

Vegetation percent composition is the measure and indicator of range status in term of grasses, forbs and browse. Grasses and forbs are collectively known as herbaceous vegetation.

Information obtained on the botanical composition of the grazing animals diets is essential for optimal allocation of forage to different types of herbivores, selecting types of grazing animals compatible with the forage resources, selecting species required for reseeding on deteriorated ranges, predicting the outcome of overgrazing by different animals, in identifying key species on which to base management and in determining the suitability of exotic animals for particular range type. The diet botanical composition of the livestock reflects a direct species composition of the natural rangelands, but it differs to some extent according to the livestock preferences in selecting these species.

Higher values of grasses in this study were in line with what was reported by Suleiman, (1987) in his study on Kordofan and Darfur Base line survey, Elnour, (2007), in Eddaein area, Elzubier, (1984) in Abu Matarique people's Council and Tahir (2003) in eastern Nyala province of South Darfur State. The above researchers showed that grasses in the Baggara country in Darfur and Kordofan, annual grasses constitute more than $80 \%$ and perennials constitute only $20 \%$ of the pasture grasses. The above researchers in studying species percentage composition on the natural pasture within the same zone reported higher values of grasses in the pasture of South Darfur and that grasses provide the bulk of livestock main feed.

Most of these grasses are considered as the main sources of livestock feed in these areas, especially during the late dry summer seasons. Elnour (2007) showed that goats usually use grasses during rainy season but in the dry summer, $60 \%$ of its diet composed of grasses and the rest reflects the amount of forbs and succulent browse.

Animal diet percent composition, as indicated in table 2 , showed that grasses were significantly higher $(\mathrm{P}<$ $0.01)$ during the first year, whereas forbs and browse were significantly higher $(P<0.05)$ during the second year. It should be recalled that during the second year rainfall averaged $825 \mathrm{~mm}$ which was almost double to that in year1 ( $430 \mathrm{~mm}$ ). This may explain why higher percentages of forbs and browse were significant during the second year since in the late dry season heavy grazing might be exerted on those species in the presence of less nutritious dry grasses.

Cattle and sheep diets on grasses were highly significant $(P<0.01)$ over goat diets, whereas forbs 
as diet for sheep and goats was significantly higher $(P<0.05)$ over cattle. On the other hand, goat diet was significantly $(P<0.01)$ dependent on browse in comparison to cattle and sheep. This would largely reflect animal behavior in grazing since cattle depends mainly on grasses, whereas goats on browse and sheep depends heavily on forbs and grasses. This variation in animal behavior feeding would show the importance of having a mixed herd under open grazing system to fully utilize the different vegetation composition available in the range.

Forbs composition in the animal diets was not affected by seasons or diets selected by the freeranging animals. Although, forbs have higher levels of Crude protein and phosphorous but sometimes containing poisonous compounds and in certain stages of growth it may be toxic to some ruminant's livestock. As dry season progresses browse is considered a major constituents of livestock diets especially during late dry summer. Browse trees and shrubs were the only solution for improving the quality of the animal feed in addition to forage shortages.

The percent species composition as a measure and an indicator of range status is a useful and easy method for obtaining such information. The livestock diet botanical composition is also a good indicator as it involves animal in studying the pasture species composition and definitely reflects a direct species constituents of the natural rangelands but it differ to some extent according to livestock preferences in selecting these species.

The reason behind the higher values of browse in the livestock diets during the late dry summer and lower values in cattle and goats diets during early dry summer is due to the fact that, in the wet grazing sites, the forage provides adequate amount of nutritious feed to cattle and sheep in the form of grasses which is preferred by these types of animals. In the late dry summer the nutritive values of the grasses decreased and may become scarce during this period at some locations. Cattle and sheep move to graze and sometime browse on shrubs and trees foliages, while goats browse all time. Higher intake of forbs and shrubs were observed in some areas within the Sahel and semi-arid zones (Nyamangara and Ndlovu 1995).

Calcium concentration in the simulated diets as presented in Table 3 ranged from 0.4 to $2.73 \%$. Calcium concentration in the three animal diets showed no difference due to the effect of years, seasons of the two years and between the different simulated diets collected from the field.

Phosphorous concentration ranged from 0.044 to $0.56 \%$ and it showed highly significant differences at $(p<0.07)$ due to the effect of seasons and the different animal diets. It showed that phosphorous concentration contained in the simulated diets was higher in the first year compared to the second year.

Table 2. Percent diets botanical composition as affected by season and animal class

\begin{tabular}{|c|c|c|c|c|c|c|c|}
\hline Factors & Periods & \multicolumn{2}{|c|}{ Grasses \% } & \multicolumn{2}{|c|}{ Forbs $\%$} & \multicolumn{2}{|c|}{ Browse \% } \\
\hline Animal diets & Years & early & late & early & late & early & late \\
\hline \multirow[t]{2}{*}{ Cattle diet } & First year & 89.00 & 92.20 & 11.00 & 7.80 & 0.00 & 0.00 \\
\hline & Second year & 85.00 & 85.00 & 11.67 & 11.67 & 3.33 & $3.33^{-}$ \\
\hline \multirow[t]{2}{*}{ Sheep diet } & Firstlyear & 87.00 & 87.33 & 13.00 & 10.67 & 0.00 & 2.00 \\
\hline & Second year & 82.67 & 83.33 & 14.33 & 13.33 & 3.00 & $3.33^{-}$ \\
\hline \multirow[t]{2}{*}{ Goats diet } & First year & 72.33 & 63.67 & 12.00 & 6.23 & 15.67 & 30.10 \\
\hline & Second year & 61.67 & 65.00 & 13.33 & 17.33 & 21.00 & 21.67 \\
\hline \multicolumn{8}{|l|}{ Main effects: } \\
\hline \multirow{3}{*}{ years } & First year & \multicolumn{2}{|c|}{$81.90 \pm 11.53 a$} & \multicolumn{2}{|c|}{$10.12 \pm 4.95 b$} & \multicolumn{2}{|c|}{$7.96 \pm 11.98 b$} \\
\hline & Second year & \multicolumn{2}{|c|}{$77.11+11.51 \mathrm{~b}$} & \multicolumn{2}{|c|}{$13.61 \pm 5.73 a$} & \multicolumn{2}{|c|}{$9.28 \pm 9.54 a$} \\
\hline & Significance & \multicolumn{2}{|c|}{$0.01^{* * *}$} & \multicolumn{2}{|c|}{$0.07^{* \star}$} & \multicolumn{2}{|c|}{$0.31^{* *}$} \\
\hline \multirow{4}{*}{ Animal Diet } & Cattle diets & \multicolumn{2}{|c|}{$87.80 \pm 5.30 a$} & \multicolumn{2}{|c|}{$10.53 \pm 4.90 \mathrm{~b}$} & \multicolumn{2}{|c|}{$1.67 \pm 3.26 b$} \\
\hline & Sheep diets & \multicolumn{2}{|c|}{$85.09 \pm 7.39 a$} & \multicolumn{2}{|c|}{$12.83 \pm 5.89$} & \multicolumn{2}{|c|}{$2.08 \pm 2.61 \mathrm{~b}$} \\
\hline & Goats diets & \multicolumn{2}{|c|}{$65.67 \pm 5.35 b$} & \multicolumn{2}{|c|}{$12.23 \pm 6.07 a$} & \multicolumn{2}{|c|}{$22.11 \pm 6.96$ a } \\
\hline & Significance & \multicolumn{2}{|c|}{$0.01^{* * \star}$} & \multicolumn{2}{|c|}{$0.61 * *$} & \multicolumn{2}{|c|}{$0.01^{* * *}$} \\
\hline
\end{tabular}

${ }^{* * *}$ highly significant at $(\mathrm{P}<0.01)$

** significant at $(p<0.05)$ 
Table 3. The nutritive values of animal diets as \% of dry matter

\begin{tabular}{|c|c|c|c|c|c|}
\hline Factors & Periods & \multicolumn{2}{|c|}{ Phosphorous \% } & \multicolumn{2}{|c|}{ Calcium \% } \\
\hline Animal class diet & Years & Early & Late & Early & Late \\
\hline \multirow{2}{*}{ Cattle } & First year & 0.05 & 0.56 & 1.13 & 0.40 \\
\hline & Second year & 0.06 & 0.04 & 1.13 & 1.53 \\
\hline \multirow{2}{*}{ Sheep } & First year & 0.08 & 0.06 & 2.40 & 0.87 \\
\hline & Second year & 0.04 & 0.08 & 1.40 & 1.93 \\
\hline \multirow{2}{*}{ Goats } & First year & 0.09 & 0.12 & 2.27 & 1.43 \\
\hline & Second year & $0.05^{-}$ & 0.06 & 0.93 & 2.73 \\
\hline \multicolumn{6}{|l|}{ Main effects: } \\
\hline \multirow{3}{*}{ (1) Years } & First year & \multicolumn{2}{|c|}{$0.08 \pm 0.04 a$} & \multicolumn{2}{|c|}{$1.28 \pm 1.14$} \\
\hline & Second year & \multicolumn{2}{|c|}{$0.06 \pm 0.02 b$} & \multicolumn{2}{|c|}{$1.61 \pm 1.65$} \\
\hline & Significance & \multicolumn{2}{|c|}{$0.07^{*}$} & \multicolumn{2}{|c|}{$0.49 \mathrm{NS}$} \\
\hline \multirow{3}{*}{ (2) Seasons } & Early dry season & \multicolumn{2}{|c|}{$0.06 \pm 0.03$} & \multicolumn{2}{|c|}{$1.54 \pm 1.16$} \\
\hline & Late dry season & \multicolumn{2}{|c|}{$0.07 \pm 0.03$} & \multicolumn{2}{|c|}{$1.34 \pm 1.64$} \\
\hline & Significance & \multicolumn{2}{|c|}{$0.59 \mathrm{NS}$} & \multicolumn{2}{|c|}{$0.68 \mathrm{NS}$} \\
\hline \multirow{4}{*}{ (3) Animal class diet } & Cattle diets & \multicolumn{2}{|c|}{$0.05 \pm 0.03$} & \multicolumn{2}{|c|}{$1.05 \pm 1.19$} \\
\hline & Sheep diets & \multicolumn{2}{|c|}{$0.06 \pm 0.02$} & \multicolumn{2}{|c|}{$1.65 \pm 1.30$} \\
\hline & Goats diets & \multicolumn{2}{|c|}{$0.08 \pm 0.48$} & \multicolumn{2}{|c|}{$1.63 \pm 1.71$} \\
\hline & Significance & \multicolumn{2}{|c|}{$0.17 \mathrm{NS}$} & \multicolumn{2}{|c|}{$0.53 \mathrm{NS}$} \\
\hline
\end{tabular}

Means within the same column followed by different superscripts are significantly different

** Significant at $(\mathrm{P}<0.05)$

* Significant at $(P<0.07)$

NS: Not Significant

McDowell (1992), stated that minerals play a unique role in animal nutrition because they are essential for the utilization of energy and protein biosynthesis of the essential nutrients. The quality of forage is controlled mainly by its mineral composition. Forage often do not satisfy mineral requirement of grazing cattle, so adequate intake of forage by the grazing ruminant is essential to meet mineral requirements (McDowell, 1996) .It is found that in most tropical pastures mineral deficiencies severely inhibit ruminant livestock production. Gomide, (1978) reported that the mineral composition of forage varies according to many factors including soil, differences among species and varieties of plants and seasons of the years.

Phosphorous deficiency is most likely to occur when ruminant graze on natural native forage (Green, 2000) while calcium is adequate in the pasture of arid and semi-arid pasture of the Sahel belt. Ward and Lardy, (2005) showed that phosphorous occur on natural pasture but with lower values in sheep diets and les than goat requirements. Yehia, (2002) in the west-central Sudan recorded a value between 0.2330.236 percent. Similar results were reported by Fadlalla (1987) in studying the Baggara sheep in the low rainfall woodland Savannah of South Kordofan. In this study the level of phosphorous in the animal diets showed low values which were in agreement with the results obtained by Green, 2000, Yehia, 2002 ,Ward and Lardy ,(2005). Calcium is quite sufficient and it was not affected by seasons or years .Small ruminant (sheep and goats) showed highest levels of calcium concentrations. $(2.43 \%)$ in the sheep diets, $(2.27 \%)$ in goats followed by cattle diets $(1.13 \%)$ in the early dry summer of the year $2006 / 2007$. In comparing these results with that in the year 2007/2008, goats diets showed highest values of calcium concentrations during late dry summer of the two years. Goats usually depend on browse during peak dry summer while sheep and goats were selective grazers.

High calcium mean values obtained in this study in the Baggara country of Dar-Rezaigat communal land might mean that ,calcium as a micro- mineral element, is abundant in all pasture all the year round , especially in small ruminants diets. Since the average phosphorous content in grasses is less than that in legumes (Dougall et.al,1964) and because the study area was dominated by grasses, which comprise more than $80 \%$ of the vegetation ,this will confirm the lower values of $\mathrm{P}$. phosphorous deficiency in this type of pasture was also reported by Fadlalla (1987). 


\section{CONCLUSIONS}

It could be concluded that livestock diets botanical composition was composed of pure herbaceous plant species during rainy and early dry summer seasons. In late dry summer season diets composition were a mixture of herbaceous and browse vegetation.

Although, the percent species composition of the natural pasture provides an indicator of range composition in term of grasses forbs and browse, livestock diets botanical composition could be used as an indicator for pasture status or range condition.

In attempt to elucidate the current seasonal changes on forage quality as shown in the assessment of some mineral concentrations in the simulated animal diets, chemical analysis was used. The study gave strong evidence in that, marginal and fragile environment provide enough feed for livestock but lacking phosphorous, although the pasture is rich in calcium and there is no reported cases in livestock utilizing these types of rangelands. The study showed that there is a great variations in the concentrations of calcium and phosphorous with the advancement of the dry summer season and between years.

The results showed and confirmed that phosphorous is the element most deficient in the semi-arid rangelands -especially in the Baggara country of Kordofan and Darfur .Calcium is considered available during all seasons of the years.

The above parameters could be very useful in designing range management practices, such as selecting species required for reseeding deteriorated range and in identifying key species that will form a base for range management.

\section{REFERENCES}

ARC (Agricultural Research Council), (1980).The nutrient requirements of ruminant livestock, $4^{\text {th }}$ eds. $C A B$ International, Wallingford, pp73-110

Box TW and Rayden AP (1971). Nomadism and land use in Somalia, economic development and cultural changes (19): p. 222-228.

Champman, H.D. and Pratt, F.P. (1961). "Calcium and Magnesium by Titration Methods" Methods of analysis for soil, plants and water California University, Davis.

Champman, H.D. and Pratt, F.P. (1968). "Ammonium molybdate-Ammonium Vandate method for determination of phosphorous, Methods of analysis for soils, plants and water, California University, Davis.

Darrag A (1990). Second forum of Mayors cities and desertification. The Case of Elodaya Desertification control Project, Kordofan Western States, (unpublished).

Dougall, H.W., Drysdale, V. M. and Glover, P. E. (1964). The chemical composition of Kenya browse and pasture herbage. East African Wildlife Journal (2): 82121.

Drinking Water Corporation annual report (2008), Eddaein Locality South Darfur State.

El-Hag, F.M., Ahmed, M.M.M., Fadlalla, B., El-Amin, E.M., El-Wakeel A.S. and Mekki, M.A. (2003). Seasonal performance of Zebu Cattle under two production systems in South Kordofan State, published by Agricultural Research Corporation,Wadmadani,Sudan.

Elham E (1988). Range resources inventory for evaluation of Elodaya Project for range rehabilitation, Sudan, M.Sc. Thesis, Institute of Environmental Studies, University of Khartoum, Sudan.

Elnour AS (2007). The potentials for resources and rural Development In: Jebel Marra -first. Edition. Khartoum: Q. P for printing and publishing Journal of Tropical Science (42), 21-29.

Elzubeir AM(1984). The environmental consequences of open grazing system in Darel-Rezeigat with special reference to Abu- Matarique popular people Council, South Darfur. M.Sc. Thesis, Institute of Environment Studies, University of Khartoum, Sudan.Elzubeir, A.M. (1984). The environmental Consequences of open grazing system in Darel-Rezeigat with special reference to Abu- Matarique popular people Council, South Darfur. M.Sc. Thesis, Institute of Environment Studies, University of Khartoum, Sudan.

Fadlalla, B. (1987). The dry season nutritional status of the transhumance Baggara sheep, Proc. International Conference on Animal production in arid zones, (ICAPAZ). Damascus, Syria: 843-844.

Gardener MR (1998). The biology of Nassella neesiana (Trin. and Ruper. Backworth (Chilean grass) in pasture on the northern Tableland of New South Wales: Weed or pasture. PhD Thesis. University of New England, Australia. Humrphey, L.R. (1991). Tropical pasture utilization (Cambridge University Press).

Gomide, J.A. (1978). Mineral composition of grasses and tropical legume forage. In: Conard, J.H. and McDwell, L.R., Latin America a symposium on mineral nutrition research with grazing ruminants, University of Florida, Gainesville, Florida.

Green, L.W.(2000).Designing mineral supplementation of forage programs for beef cattle. Proceedings of the American Society of Animal Science.

Hans Rothenberg (1976). Farming systems in the tropics, Clarindon, Press, Oxford. 
Harrison MN (1955). A report on grazing survey for the Sudan. Khartoum mimeographed- and better known as (Harrison report).

Harrison MN and Jackson JK (1958). Ecological classification of the vegetation of the Sudan. Forest Bulltein No. (2), (New series). Publication committee, Khartoum, Sudan.

Heady H F (1975). Range Management. McGraw-Hill, New York pp. 460.

Holecheck J (1983). Range livestock Nutrition problems and research approaches in western Sudan, In: International Publication New Mexico State University, Las Cruces, New Mexico, 88003-3567 Staff Report (BIFAD). Consulting Activities.

Hunter JP (1990).SADCC Workshop discusses problems and prospects for improved rangeland Management. News letter 9 (4): 4-5.

Ibrahim F (1962). Ecological and Human possibilities and Constraints of development of traditional pastoralists of the nomads of western Sudan, In: IFO, Munchen Intress.

Le Houerou HN (1980). Role of browse in the Sahelian and Sudanian Zones, In: Browse in Africa, The current state of knowledge, H. N. Le Houero (ed), ILCA, Addis Ababa, Ethiopia.

Lewis I. M (1961). A pastoral Democracy, Oxford University Press, London.

McDowell, L.R. (1992). Free choice mineral supplementation and methods for mineral evaluation. In: Nutrition of grazing ruminants in worm climates, Academic Press, Inc. San Diego, pp. 383-407.

McDowell, L.R. (1996). Feeding minerals to cattle on pasture. Animal Feed Science and Technology (60). 247-271Nyamangara ME and Ndlovu LR (1995). Feeding behaviour, feed Intake, chemical and botanical composition of the diets of goats raised on natural vegetation in a semi-arid region of Zimbabwe Journal of Agricultural Science (Cambridge), 124: 455461.
Parker KW (1951). A method for measuring trend in range condition on national forest ranges. U. S. Forest Service, Washington (mimeo).

Skerman PJ (1965). Ecological Observation of studies in Kordofan Special Fund Project, FAO (1962-1965).

Steel RGD and Torrie JH (1980). Principles and procdures of statistics a biometrical approach. $2^{\text {nd }}$ ed. McGraw Hill, Company, NewYork, USA, 633 p.

Stoddart L A Smith $A D$ and Box , T.W.(1975) . Range management, Mc Graw -Hill, New York.

Suleiman M M (1987). Baseline Survey for Kordofan and Darfur.

Suleiman MM and Darrag A (1982). Desertification with special emphasis on carrying capacity and pasture resources, present assets of Natural Resources Issue in Sudan, Institute of environmental studies, University of Khartoum Sudan.

Tahir AM (2003). Range Improvement by Inter-seeding and water conservation in the semi-arid zone of the Sudan: Nyala, S. Darfur.

Van Dyne GM (1968). Measuring quantity and quality of the diets of large herbivores. In: Practical Guide to study of the productivity of large herbivores F.B. Galley and H.K. Bukgner, eds. Blackwell Scientific Publication, Oxford, England.

Ward, M. and Lardy, G. (2005). Beef cattle mineral nutrition. AS-1287.NDSU Extension service, North Dakota State University.

Whalley RDB (2000). Grasslands, grazing animals and people. How do they fit together. Tropical grasslands, 34: 192-198.

Whalley RDB Gardener MR and Earl JE (1999). Pasture management of reproductively efficient grassy weeds, $12^{\text {th }}$ Australian Weeds Conference, Hobart, Tasmania, Tasmanian Weeds Society

Yehia, E.O. (2002). Ecology of some herbaceous forage species, North Kordofan State, MSc. Thesis, Institute of Environmental Studies University of Khartoum. 